\title{
Towards Network Perspective of Intra- Organizational Learning: Bridging the Gap between Acquisition and Participation Perspective
}

\author{
Miha Škerlavaj and Vlado Dimovski \\ University of Ljubljana, Faculty of Economics, \\ Ljubljana, Slovenia
}

\section{miha.skerlavaj@ef.uni-li.si vlado.dimovski@ef.uni-li.si}

\begin{abstract}
Organizational learning is a scientific field of growing importance. It has developed from classic and foundational works to the two disparate perspectives today: the acquisition and the participation perspective. The first understands knowledge as a substance, mind as a container, and learning as a transfer of a substance from one mind to another. The second perspective focuses on communities of practice and observes no teaching but rather goal-directed practical learning. We argue that both are incomplete and that there is a need for overarching perspective that would build upon multiple-theoretical and multi-level framework of social network theories. Beside connecting acquisition and participation perspective it addresses organizational learning as a multiplex and dynamic process at individual, group, intra-organizational, as well as relational level of research. This contribution proposes network perspective to intra-organizational learning and develops seven descriptive claims to be tested using real-life case studies of social networks within organizations. Both exploratory and confirmatory social network techniques are to be applied.
\end{abstract}

Keywords: organizational learning, acquisition perspective, participation perspective, network perspective, social network analysis, descriptive claims.

\section{Introduction}

Organizational learning has emerged as one of the most promising concepts in strategic management literature in late 1980s in relation to the concept of competitive advantage. Nevertheless, the concept of organizational learning stretches much farther and is embedded also in different schools of thought, including contingency theory, organizational development, industrial economy, information theory and system dynamics, systems theory, management science, production and operation management, social anthropology, sociology, psychology, and organizational theory. As such, it is founded on very different theoretical assumptions that need to be viewed as

Material published as part of this publication, either on-line or in print, is copyrighted by the Informing Science Institute. Permission to make digital or paper copy of part or all of these works for personal or classroom use is granted without fee provided that the copies are not made or distributed for profit or commercial advantage AND that copies 1) bear this notice in full and 2) give the full citation on the first page. It is permissible to abstract these works so long as credit is given. To copy in all other cases or to republish or to post on a server or to redistribute to lists requires specific permission and payment of a fee. Contact Publisher@InformingScience.org to request redistribution permission. complementary to each other in the understanding of organizational learning field (Dodgson, 1993; Easterby-Smith, 1997; Romme \& Dillen, 1997;

Shrivastava, 1983).

Organizational learning is one of the most important sources of a sustainable competitive advantage that companies have (de Geus, 1988) as well as an important driver of corporate performance (Stata, 1989). Given the turbulent envi- 
ronments that organizations work within, continuous learning is a key driver of their ability to remain adaptive and flexible - that is to survive and effectively compete (Burke et al., 2006). Studies have shown that it affects competitive advantage (Jashapara, 2003), financial and nonfinancial performance (Bontis, Crossan, \& Hulland, 2002; Dimovski \& Skerlavaj, 2005), tangible and intangible collaborative benefits in strategic alliances (Simonin, 1997), the unit cost of production (Darr, Argote, \& Epple, 1995), and innovation (Llorens Montes, Ruiz Moreno, \& Garcia Morales, 2005).

In recent years, academic sphere has witnessed a dual development of the field. At one hand, researchers have been developing acquisition perspective which considers the mind as being a container, knowledge as a substance and learning as the transfer and addition of substance to mind. At the other hand, the participation perspective derives from studies of learning in which no teaching was observed and understands learning as participation in communities of practice (Lave $\&$ Wenger, 1991). Still, there are some indications that both of the perspectives are incomplete for full understanding of organizational learning. Elkjaer (2004) suggests so called 'third way' which is an attempt to make a synthesis of the participation perspective and communities of practice by including elements of learning as acquisition of knowledge as well as analytical and communicative skills. By all means, the content and the process of learning are not 'visible' as in a chemical experiment and that learning takes place as a social process, rather than a system or just in communities of practice. Nevertheless, the 'third way' seems to put too much emphasis on participation perspective and neglects some vital aspects of acquisition perspective.

In the intra-organizational learning network perspective, as proposed here, synthesis needs to be done in such a way that an individual is recognized as a primary source and destination for learning, while acknowledging that learning takes place primarily in social interaction based on several theories of social networks. Hence, we argue that learning network perspective seems to describe organizational learning better than its predecessors.

This contribution aims to develop theoretical foundations for the network perspective to intraorganizational learning. First, it provides an overview of several definitions of organizational learning and briefly describes the historical development of the field. Second, it contrasts acquisition and participation perspective to organizational learning and lays a path for the development of network perspective. It does so by resting upon multiple theories of social networks and by applying a multi-level approach. Authors also introduce considerations of multiplexity and dynamics in the network perspective to organizational learning. As the final result of this paper seven descriptive claims to be tested empirically in future research are proposed.

\section{Organizational Learning Field}

\section{Definitions}

Organizational learning is a field of study that was developed in several disciplines by many researchers using a variety of different perspectives (Bontis, Crossan, \& Hulland, 2002; Dimovski, 1994; Shrivastava, 1983). In Table 1 various definitions of organizational learning are briefly outlined. The common trait in the majority of definitions is that they consider organizational learning as a process that has to do with transforming information into knowledge (e.g. Argyris \& Schön, 1978; Crossan, Lane, White, \& Djurfeldt, 1995; Day, 1994; Dimovski, 1994; Fiol \& Lyles, 1985; Huber, 1991; Lee, Courtney, \& O’Keefe, 1992). Definitions differ in the way they extend (or not) the information processing (information acquisition, interpretation, and storage in the organizational memory) to behavioral and cognitive changes (Crossan et al., 1995; Dimovski, 1994; Kim, 1993; Slater \& Narver, 1995). In addition, Sanchez (2001) extends the understanding of organiza- 
tional learning to multiple levels, while Schwandt \& Marquardt (2000) explicitly render the need to understand organizational learning as relational phenomena.

Table 1: Definitions of organizational learning

\begin{tabular}{|c|c|}
\hline Author(s) & Definition \\
\hline Argyris \& Schön (1978) & Organizational learning is a process of detecting and correcting errors. \\
\hline Daft \& Weick (1984) & $\begin{array}{l}\text { Organizational learning is knowledge about the interrelationships between the organiza- } \\
\text { tion's action and the environment. }\end{array}$ \\
\hline Fiol \& Lyles (1985) & $\begin{array}{l}\text { Organizational learning means the process of improving actions through better knowl- } \\
\text { edge and understanding. }\end{array}$ \\
\hline Stata (1989) & $\begin{array}{l}\text { Organizational learning is the principal process by which innovation occurs. In fact, I } \\
\text { would argue that the rate at which individuals and organizations learn may become the } \\
\text { only sustainable competitive advantage, especially in knowledge-intensive industries. }\end{array}$ \\
\hline Huber (1991) & $\begin{array}{l}\text { An entity learns if through its processing of information the range of its potential behav- } \\
\text { iors is changed. }\end{array}$ \\
\hline Lee et al. (1992) & $\begin{array}{l}\text { The organizational learning process is viewed as a cyclical one in which individual's } \\
\text { actions lead to organizational interactions with the environment. Environmental re- } \\
\text { sponses are interpreted by individuals who learn by updating their beliefs about cause- } \\
\text { effect relationships. }\end{array}$ \\
\hline Kim (1993) & $\begin{array}{l}\text { Organizational learning is defined as increasing an organization capacity to take effec- } \\
\text { tive action. }\end{array}$ \\
\hline Levinthal \& March (1993) & $\begin{array}{l}\text { Organizational learning copes with the problem of balancing the competing goals of } \\
\text { developing new knowledge (exploration) and exploiting current competencies (exploita- } \\
\text { tion) in the face of dynamic tendencies to emphasize one or another. }\end{array}$ \\
\hline Day (1994) & $\begin{array}{l}\text { Organizational learning is comprised of the following processes: open-minded inquiry, } \\
\text { informed interpretations, and accessible memory. }\end{array}$ \\
\hline Dimovski (1994) & $\begin{array}{l}\text { Organizational learning is a process of information acquisition, information interpreta- } \\
\text { tion and resulting behavioral and cognitive changes, which should in turn have impact } \\
\text { on organizational performance. }\end{array}$ \\
\hline Crossan et al. (1995) & $\begin{array}{l}\text { Learning is a process of change in cognition and behavior, and it does not necessarily } \\
\text { follow that these changes will directly enhance performance. }\end{array}$ \\
\hline Slater \& Narver (1995) & $\begin{array}{l}\text { At its most basic definition, organizational learning is the development of new knowl- } \\
\text { edge or insights that have the potential to influence behavior. }\end{array}$ \\
\hline $\begin{array}{l}\text { Schwandt \& Marquardt } \\
(2000)\end{array}$ & $\begin{array}{l}\text { Organizational learning represents a complex interrelationship between people, their } \\
\text { actions, symbols, and processes within the organization. }\end{array}$ \\
\hline Sanchez (2001) & $\begin{array}{l}\text { Organizational learning aims to generate, disseminate, and apply knowledge in an or- } \\
\text { ganization. It consists of five learning cycles: (1) individual, (2) individual/group, (3) } \\
\text { group, (4) group/organizational, (5) organizational. }\end{array}$ \\
\hline
\end{tabular}

Sources: Adapted from Bontis, Crossan, \& Hulland, 2002; Dimovski, 1994; Shrivastava, 1983; Sanchez, 2005.

\section{Development of the field}

Organizational learning field of research has a long and outstanding tradition. Initial ideas about learning date to the year 1916 (Dewey, 1916). Organizational learning literature through time can be organized in three eras: (1) emergence of classical works; (2) spread of foundational works; and (3) separation of acquisition and participation perspective. The role of organizational learning in the modern management literature is gaining in importance. Figure 1 presents the historical development of organizational learning field through time and examines its role in the modern scientific literature. 


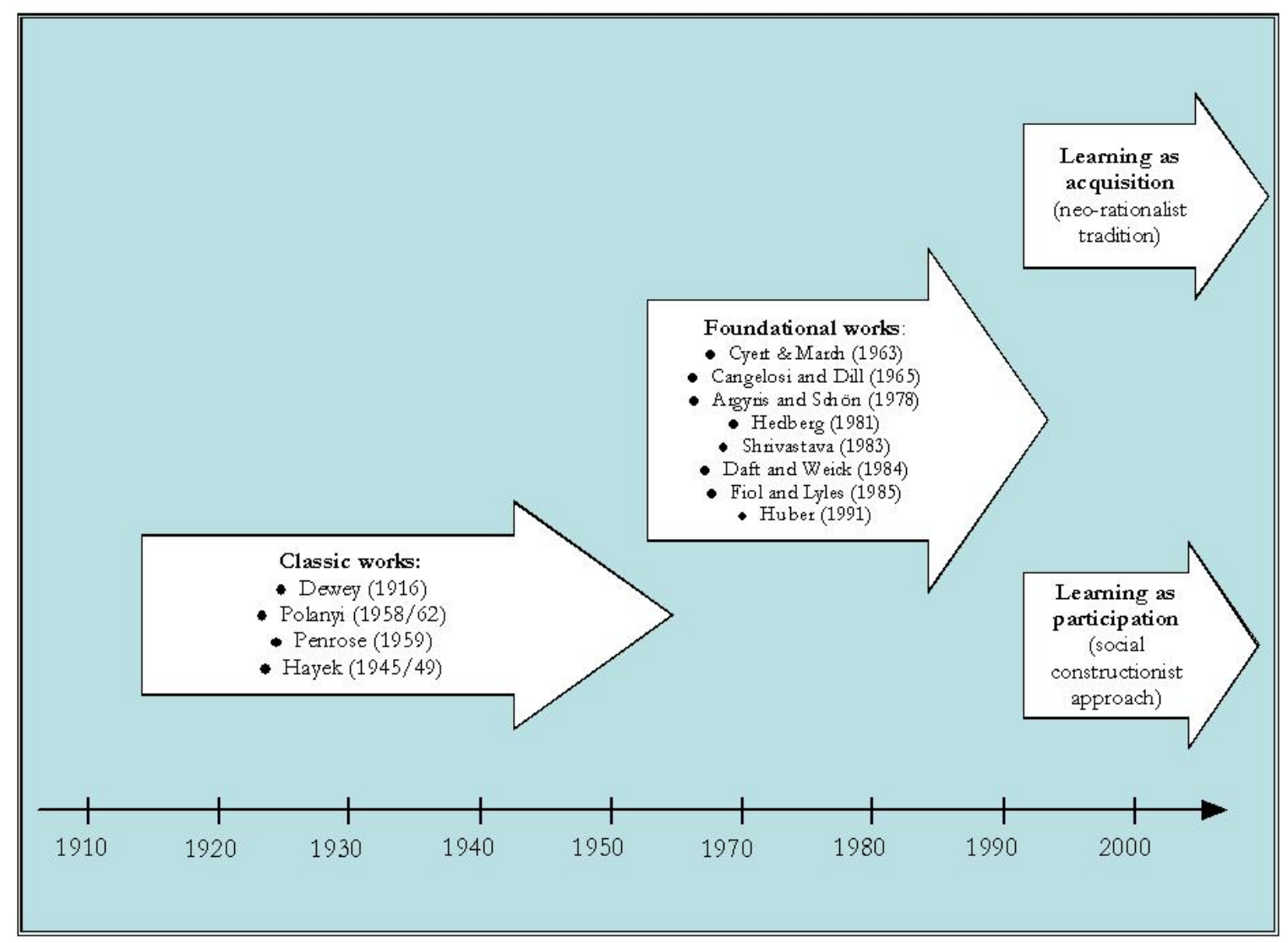

Figure 1: Timeline of organizational learning field development

Source: Own; Based on Easterby-Smith and Lyles, 2004; Elkjaer, 2004.

Even before the mentioning of organizational learning term, several authors were active in the field and have significant impact on today's contributions in the area. Easterby-Smith \& Lyles (2004) rate them as authors of classical works and mention John Dewey, Michael Polanyi, Edith Penrose, and Frederick Hayek. Philosopher Dewey (1916) explicitly focused on learning and developed ideas of learning from experience, which impact individual level of organizational learning works. It also influences the view that learning takes place through social interaction and that cannot be passed from person to person as if it were a physical object.

The first foundational work in the area was book by Cyert \& March (1963) which first articulated the idea that an organization could learn in ways that were independent of the individuals within it. Their general theory of organizational learning as a part of a model of decision making within the firm was a key breakthrough in the field and highlights the role of rules, procedures, and routines as a reaction to external shocks and which are more or less likely to be adopted according to whether or not they lead to positive effects for organization. Suggestions from the book worth mentioning at this point are that firm adapts to its environment through its environment, and that 'firm learns from its experience' (1963: 100).

According to Easterby-Smith and Lyles (2004), Cangelosi and Dill (1965) published the first work in which the words 'organizational learning' appeared in the title, and start to argue against the neo-rationality of Cyert and March model and proposed that the model might be appropriate for established organizations in stable circumstances, but has limited relevance to organizations developing within dynamic circumstances. Argyris and Schön (1978) joined the critique of Cyert and March, yet from different perspective. They have pointed out that the rationalist assumptions 
very often do not seem to describe actual human behavior within organizations. They also provided the distinction between organizations with and without the capacity to engage in significant learning (Models II and I). Easterby-Smith and Lyles (2004) identify a number of other foundational works in 1970s and 1980s, such as Hedberg (1981), Shrivastava (1983), Daft and Weick (1984), and Fiol and Lyles (1985), which mainly dealt with definitions of terminology and with deepening of perspectives of organizational learning.

Another turning point in the development of organizational learning area was the publication of the Special Edition of Organization Science in 1991, which includes number of highly cited articles such as March (1991), Huber (1991), Epple, Argote, and Devadas (1991), and Simon (1991). In general, these articles follow the neo-rationalist tradition, which suggest that it is desirable to maximize the efficient use of knowledge in organizations, while recognizing that there are substantial, mainly human, obstacles in its way (Easterby-Smith \& Lyles, 2004). However, in the same issue of Organization Science, an article by Brown \& Duguid (1991) triggered an alternative stream of research which focuses upon the social processes of organizational learning (for instance: Bartel \& Garoud, 2004; Cross \& Prusak, 2004; Lave, 1988; Nicolini \& Meznar, 1995). Similarly, Elkjaer (2004) noticed distinction between acquisition and participation metaphor to organizational learning.

Focus on individual acquisition of skills and knowledge as a point of departure for organizational learning and the learning organization has been criticized centering upon individual mind processes and a concept of knowledge that stresses the importance of abstract thinking (Cook \& Brown, 1999; Nicolini, Gherardi, \& Yanow, 2003). As an alternative, it has been proposed that learning takes place through participation in communities of practice and with a point of departure in concrete organizational practices.

\section{Perspectives to Organizational Learning}

In the current organizational learning thinking, two contrasting perspectives for organizational learning collide. In the acquisition perspective, the mind is viewed as being a container, knowledge as a substance and learning as the transfer and addition of substance to mind, while the participation perspective derives from studies of learning in which no teaching was observed and understand learning as participation in communities of practice (Lave \& Wenger, 1991). The authors add the learning network perspective, which combines first two in terms of learning content and method, while it upgrades them in terms of view of organization. The following contribution aims to contrast acquisition and participation perspective to organizational learning and to develop a network perspective to intra-organizational learning.

\section{Acquisition vs. Participation Perspective}

The acquisition perspective underlies much of the early literature on organizational learning (Cyert \& March, 1963; Huber, 1991; March \& Simon, 1958). This view on organizational learning comprises an understanding of learning as individual acquisition of knowledge and skills. The mind is viewed as being a storage place, knowledge as an essence and learning is the transfer and accumulation of essence to mind. This understanding of learning is predominant because it reflects an understanding of learning known from formal education. According to the acquisition perspective theory, knowledge is a package that you transfer to somebody else.

A major critique of the acquisition perspective is that it neglects the fact that learning is also a social process heavily dependent upon the dimensions of relations among organizational members. For instance, for learning to happen it is not enough that person A wants to acquire it. There are several necessary preconditions. First, there is an issue of person B who is willing and capable of teaching the person B. Here the issue of trust, accessibility and engagement (Cross, Parker, 
Prusak, \& Borgatti, 2001) are crucial. Second, this person, must be able to absorb the knowledge that person B has (Cohen \& Levinthal, 1990). The acquisition of information and its reformulation into knowledge happens in relationships among people and extends from individual to group and intra-organizational level. This is something that acquisition perspective does not account for.

Participation perspective on the other hand is derived from practice-based studies (e.g. apprenticeships learning) in which no teaching was observed (Lave \& Wenger, 1991). Within this perspective, learning is understood as participation in communities of practice $(\mathrm{CoP})$ - as a movement from newcomer to old-timer. The participation perspective takes learning out of the individual mind and formal education settings and places it into the everyday organizational life and work as illustrated by Pahor, Dlesk, Lisjak, and Zdouc (2004) in context of Slovenian multinational company.

While the participation perspective manages to consider organizational learning as relational phenomena it does so only at one particular sort of learning - that is learning by doing. In this respect it disregards a vast array of other types of learning and also neglects the acquisition perspective.

As such both of the perspectives seem to be rather incomplete in the explaining of organizational learning process within organizations. The acquisition perspective seems to neglect the aspect of learning as relational phenomena (Schwandt \& Marquardt, 2000), while the participation perspective disregards the role of individual within the organization and defines organizational learning too narrowly. Network perspective to intra-organizational learning aims to merge and expand these two disparate perspectives by building upon multiple social network theories and by examining learning process at individual, group, and intra-organizational level.

\section{Network Perspective}

It would be unfair to say that there were no indications in the past that both of the perspectives are incomplete for better understanding of organizational learning. Elkjaer (2004) departed from pragmatic theory and suggested so-called 'third way' which is an attempt to make a synthesis of the participation perspective and communities of practice by including elements of the learning as acquisition of knowledge as well as analytical and communicative skills. I agree that the content and the process of learning are not 'visible' as in a chemical experiment and that learning takes place as a social process, rather than system or just in communities of practice.

In the network perspective to intra-organizational learning, synthesis of acquisition and participation perspective needs to be done in such a way that individual is recognized as a primary source and destination for learning (the 'first way'), while acknowledging that learning takes place primarily in social interaction (the 'second way'). In such an attempt, network perspective to intraorganizational learning build upon Elkjaer's (2004) 'third way' and upgrades expands the understanding of organizational learning as both relational and individual-level phenomena to multiple levels of research (individual, group, intra-organizational, and relational).

As a synthesis of previous elaborations Table 2 contrasts the acquisition and participation perspective for organizational learning as seen by Elkjaer (2004) and upgrades them with the network perspective to intra-organizational learning. The latter combines learning content and methods of both previous perspectives, organizes organizational learning as social worlds, and addresses the research at relational, individual, group, and intra-organizational level. 
Table 2: Three perspectives to organizational learning

\begin{tabular}{|c|c|c|c|}
\hline & Acquisition perspective & $\begin{array}{c}\text { Participation perspec- } \\
\text { tive }\end{array}$ & Network perspective \\
\hline Learning content & $\begin{array}{c}\text { To be skilled and } \\
\text { knowledgeable about } \\
\text { organizations. }\end{array}$ & $\begin{array}{l}\text { To become a skilful } \\
\text { practitioner in organiza- } \\
\text { tions. }\end{array}$ & $\begin{array}{c}\text { To be skilled and } \\
\text { knowledgeable about } \\
\text { organizations and to } \\
\text { become a skilful practi- } \\
\text { tioner in organizations. }\end{array}$ \\
\hline Learning method & $\begin{array}{l}\text { Acquisition of skills and } \\
\text { knowledge }\end{array}$ & $\begin{array}{l}\text { Participation in commu- } \\
\text { nities of practice }\end{array}$ & $\begin{array}{l}\text { Acquisition of skills and } \\
\text { knowledge and partici- } \\
\text { pation in communities } \\
\text { of practice }\end{array}$ \\
\hline Organization & System & Communities of practice & Social worlds \\
\hline Level of research & Individual & Relational & $\begin{array}{l}\text { Multiple levels (individ- } \\
\text { ual, group, intra- } \\
\text { organizational) \& rela- } \\
\text { tional level }\end{array}$ \\
\hline
\end{tabular}

Source: Adapted from Elkjaer, 2004; Own.

\section{Multiplexity}

One needs to take into the consideration that organizational learning is not stand-alone process. According to a broader structural theory of collective action (Lazega, 2001) it could be assumed that learning networks are embedded in other types of networks such as friendship network, advice networks, and trust networks as outlined in Table 3. This argument has been supported also with Granovetters' (1992) claim that economic transactions are often embedded in social relations. In following subsections traits and types of learning networks will be described in order to assess in which other networks they might be embedded. Above all one might expect that learning networks are embedded with advice networks (which are often used even as a proxy for learning networks), innovation testing networks, support in decision making networks etc.

The issue of multiplexity is important in the modern network literature and generally adds to the understanding of complexity in network analysis. It is reasonable to expect that the learning process involves other intra-organizational communication processes, while people mostly learn in interaction with one another.

Also interesting is the issue of multiplexity and performance. Lazega (2001) coined the term Blau-ties, which are a compound of reciprocal strong coworker ties and unidirectional advice ties. They are important because they have an empirically validated strong and positive impact of the individual performance of employees in a collegial, knowledge-intensive organization. Apparently, there is a very clear relationship between multiplexity and performance.

\section{Dynamics}

Several social network theories suggest explicitly or implicitly that networks evolve through time. Thus, it is important to devote necessary attention to the temporal and dynamic dimension of the process of intra-organizational learning (Bapuji \& Crossan, 2004; Crossan et al., 1995; EasterbySmith, Crossan, \& Nicolini, 2000).

Recent research (Lazega, Lemercier, \& Mounier, 2006) has started to lay the path for better understanding of dynamic and longitudinal dimension into the research on intra-organizational 
learning. Based on their findings on observations of advice networks among judges at the Commercial Court of Paris in three different points, Lazega, Lemercier, and Mounier (2006) propose and test heuristics of a spinning top model. It suggests that advice networks behave similarly to spinning top. Namely, they have three components: a rotating body, a rotation axis, and a fragile equilibrium that partially depends on the characteristics of the previous components.

A rotating body is compared against the learning organization (p. 3) and is in this particular context largely dependent upon the fact that a vast majority of members of the Court rotate their jobs on a one year basis in order to allow impartiality and prevent corruption or conflicts of interests. A rotation axis represents a few stable members of the court (senior judges, presidents of the Chambers - subunits of the Court) who happen to have also the most experience in the field. Due to their expertise and status power they tend to be the most central actors within the networks and are sometimes referred to as having what is termed 'cognitive status' (Lazega et al., 2006). However, their results showed an oscillation in the in-degree centrality of these members. While in the first period of time they tend to be sought for advice even more, in the second period a process of decentralization started to happen. Due to overload of advice requests they started to delegate advisory work to other, previously less central members of the network. It is a reasonable deduction that equilibrium between the rotation movement of organizational members and the stability of rotation axis is fragile. The number of members with the cognitive status seems to be volatile over time.

The conceptualization of organizational learning process used in this work is somehow different from understanding that advice networks equal organizational learning. Following the tradition of Huber (1991), Dimovski (1994), Dimovski and Škerlavaj (2005), authors understand intraorganizational learning as a broader concept which involves information acquisition, interpretation, and also resulting behavioral and cognitive changes which are needed in order to say that learning has really happened. In such a context, advice mainly involves inter-personal aspects of information acquisition and interpretation phase of organizational-learning process. Despite this difference in conceptualization, a spinning top model seems to be useful heuristics in need for further examination in other settings where there is a lateral movement. Additional generalizability of research finding might be assured using other types of knowledge-intensive organizations, where there is less job rotation.

\section{Towards descriptive claims about network perspective}

In the development of network perspective to intra-organizational learning the authors stand on the shoulders of giants that worked in the area of social communication theories and applied a Multi-theoretical and multi-level framework - MTML (Monge \& Contractor, 2003) to the understanding of organizational learning process as both individual, group, and organizational (Sanchez, 2005) as well as a relational phenomena.

Intra-organizational learning network perspective is based on theories of homophily and proximity (Brass, 1995; Sherif, 1958; Turner \& Oaks, 1986), theory of social exchange (Blau, 1995, 1964; Homans, 1950, 1958), cognitive theories (Kogut, Shan, \& Walker, 1993; Krackhardt, 1987), theories of resource interdependence (Lindenberg, 1997), theory of small worlds (Milgram, 1967; Pool \& Kochen, 1978; Watts, 1999), transactive memory systems (Cross \& Parker, 2002; Cross et al., 2001; Heald, Contractor, Koehly, \& Wasserman, 1998; Hollingshead, 2000), social process theory (Lazega \& Pattison, 2001), theories of evolution (Aldrich, 1972; Baum, 1996) and broader theory of collective action (Lazega, 1992, 2001, 2006). It addresses organizational learning at actor, dyad, triadic, and network level. In addition, it attends to multiplexity and embededness (Granovetter, 1992) of organizational learning networks in other forms of networks. Besides, it offers a framework to reflect upon the dynamic evolution of learning networks.

Based on multiple theories of social networks and addressing intra-organizational learning proc- 
ess as multiple-level, multiplex, and dynamic process the paper offers seven descriptive claims to be tested on real life case studies of social networks. Descriptive claims are presented in the Table 3 .

Table 3: Descriptive claims about intra-organizational learning networks

\begin{tabular}{|c|c|c|c|c|}
\hline$\#$ & Claim & $\begin{array}{l}\text { Examples of specific } \\
\text { measures used to test } \\
\text { descriptive claims }\end{array}$ & $\begin{array}{l}\text { Social network the- } \\
\text { ory }\end{array}$ & $\begin{array}{l}\text { Level of } \\
\text { analysis }\end{array}$ \\
\hline DC1 & $\begin{array}{l}\text { The most central people in the learning } \\
\text { networks share some common traits (e.g. } \\
\text { experience). }\end{array}$ & $\begin{array}{l}\text { Indegree and be- } \\
\text { tweeness centrality }\end{array}$ & Cognitive theories & Actor level \\
\hline $\mathrm{DC} 2$ & $\begin{array}{l}\text { Individuals have ties with whom they share } \\
\text { similar attributes. }\end{array}$ & $\begin{array}{l}\text { Actor characteristics: } \\
\text { gender, tenure, educa- } \\
\text { tion, hierarchical } \\
\text { level, geographical } \\
\text { location. }\end{array}$ & $\begin{array}{l}\text { Theories of homo- } \\
\text { phily and proximity }\end{array}$ & $\begin{array}{l}\text { Dyadic } \\
\text { level }\end{array}$ \\
\hline DC3 & $\begin{array}{l}\text { Learning ties are not reciprocated but rather } \\
\text { asymmetric ties. }\end{array}$ & $\begin{array}{l}\text { Mutuality, reciproca- } \\
\text { tion }\end{array}$ & $\begin{array}{l}\text { Theories of social } \\
\text { exchange and re- } \\
\text { source (in- } \\
\text { ter)dependence }\end{array}$ & $\begin{array}{c}\text { Dyadic } \\
\text { level }\end{array}$ \\
\hline DC4 & $\begin{array}{l}\text { There is a tendency towards consistency in } \\
\text { relations (if A learns from B and B from C, } \\
\text { then A also learns from the C). }\end{array}$ & Transitivity & $\begin{array}{l}\text { Theory of generalized } \\
\text { exchange }\end{array}$ & $\begin{array}{l}\text { Triadic } \\
\text { level }\end{array}$ \\
\hline DC5 & $\begin{array}{l}\text { Learning happens in internally-well con- } \\
\text { nected clusters that are externally less con- } \\
\text { nected. }\end{array}$ & $\begin{array}{l}\text { Clustering coefficient, } \\
\text { average shortest path }\end{array}$ & $\begin{array}{l}\text { Theory of small } \\
\text { worlds }\end{array}$ & $\begin{array}{c}\text { Global } \\
\text { level }\end{array}$ \\
\hline DC6 & $\begin{array}{c}\text { Organizational learning networks are em- } \\
\text { bedded in (or overlap with) other types of } \\
\text { organizational networks (e.g. advice, } \\
\text { friendship). }\end{array}$ & $\begin{array}{l}\text { Multiplexity of learn- } \\
\text { ing with advice, inno- } \\
\text { vation, decision- } \\
\text { making or friendship } \\
\text { networks }\end{array}$ & $\begin{array}{l}\text { Convergence theory } \\
\text { of communication } \\
\text { Cognitive theories } \\
\text { Transactive memory } \\
\text { system } \\
\text { Social process theory }\end{array}$ & $\begin{array}{l}\text { Other rela- } \\
\text { tions }\end{array}$ \\
\hline DC7 & $\begin{array}{c}\text { Presence or absence of ties in a relation at } \\
\text { previous point in time has an impact on } \\
\text { structure of relationships at present point in } \\
\text { time. }\end{array}$ & $\begin{array}{l}\text { Dynamic development } \\
\text { of learning network } \\
\text { (comparison at several } \\
\text { points in time) }\end{array}$ & $\begin{array}{l}\text { Theories of evolution } \\
\text { Spinning-top model of } \\
\text { organizational learn- } \\
\text { ing }\end{array}$ & $\begin{array}{l}\text { Relation at } \\
\text { previous } \\
\text { point in } \\
\text { time }\end{array}$ \\
\hline
\end{tabular}

Descriptive claim 1 (DC1) is based on cognitive theories of social networks and in particular transactive memory theory (Hollingshead, 2000; Moreland, 1999). While transactive memory system facilitates learning and reduces the need for each organizational member to possess skills or knowledge available elsewhere in the network, it also causes that those few people who are already knowledgeable will be more often targeted as a source of learning. There are several authors (Hollingshead, 2000; Wegner, Erber, \& Raymond, 1991) that claim that individuals focus on learning in their own areas of expertise. This leads authors to assume, that each organizational unit (department, sector etc) within unit will have at least one central employee. The paper extends this theoretical background one step further to explore whether there are some common traits of the most central people in the whole organization. Descriptive claim 1 addresses the organizational learning process at the actor (individual) level. 
Descriptive claim 2 (DC2) moves from actor to dyadic level and is based upon theories of homophily (Brass, 1995; Lazega \& van Duijn, 1997) and theories of proximity (Festinger, Schachter, \& Back, 1950; Korzeny \& Bauer, 1981; Monge, Rothman, Eisenberg, Miller, \& Kirstie, 1985). The general idea of these theories is that being close or similar eases establishing and maintaining learning relationships. Homophily and proximity have been studied in many different ways. This paper will address similarity in terms of gender, education, tenure, hierarchical position within the company, and physical proximity (working at the same geographical position and belonging to the same organizational unit).

Another claim at the dyadic level of analysis is based upon the theories of social exchange (Blau, 1955, 1964; Emerson, 1962; Homans, 1950, 1958) and resource interdependence (Lindenberg, 1997). Descriptive claim 3 (DC3) builds upon this knowledge and assumes that when people contribute something in the relationship they expect something that is valuable to them in return. In learning relationships cases where teacher can be at the same time also student are rare. It is unrealistic to expect mutuality, but rather asymmetric ties within the learning networks. Nevertheless, there is something that most central sources of learning should get in return (e.g. cognitive status).

Descriptive claim 4 (DC4) explores intra-organizational learning networks at triadic level of analysis. Generalized exchange (Emerson, 1976) is considered to be a mechanism that enhances the solidarity. In the context of learning networks, a measure to test this kind of claim is transitivity.

At the global level of learning network, theory of small worlds (Milgram, 1967; Pool \& Kochen, 1978; Watts, 1999) assumes that the existence of so called 'caveman worlds' for which high local clustering and short global separation are evident. With regard to the learning networks one might expect that people will learn in smaller, well-connected groups, which will more loosely connected among themselves as within. These groups might be organized by departments, geographical locations, and different fields of expertise as Hollingshead (2000) expects. Descriptive claim 5 (DC5) aims to test the validity of this theory for learning networks.

Descriptive claim 6 (DC6) argues that organizational learning networks are not stand-alone. Social process theory (Lazega \& Pattison, 2001) in particular emphasizes the fact that this is a common trait of social processes such as learning certainly is. While this list is far from conclusive, one might consider multiplexity of learning networks with advice, innovation testing, support in decision-making and with friendship networks.

While acknowledging the fact that organizational learning is not a stand alone process, it is also not isolated at certain point in time. Rather, learning networks have an important dynamic dimension. Descriptive claim 7 (DC7) aims to examine development of learning network through time and is based upon evolutionary theories (Aldrich, 1974; Baum, 1996) and previous empirical work in the field (Lazega et al., 2006).

\section{The implementation model - Social network analysis}

Having developed seven descriptive claims which build general framework for the network perspective towards intra-organizational learning, the next issue is how to test the descriptive claims. Authors suggest using social network analysis and also point to an initial attempt where this has been done (for reference see Škerlavaj \& Dimovski, 2006).

Social networks are seen as a specific set of linkages among a defined set of persons, with the additional property that the characteristics of these linkages as a whole may be used to interpret the social behavior of the persons involved (Mitchell, 1969). The social network approach views organizations in society as a system of objects (e.g. people, groups and organizations) joined by variety of relationships. Not all pairs of objects are directly joined and some are joined by multiple relationships, hence guiding us to also reflect upon the matter of learning network multiplex- 
ity. Network analysis is concerned with the structure and patterning of these relationships and seeks to identify both their causes and consequences (Tichy, Tushman, \& Fombrun, 1979). The network analysis mostly examines the system-wide effects instead of the characteristics of actors, even though more recent applications started to combine both relational and actor characteristics. As an alternative to viewing a relationship in isolation, it treats a relationship as a gateway to other relationships through which knowledge or resources may be reached (Easton, 1992).

Social network analysis (SNA) provides a visualized graphic and mathematical analysis of a complex human interaction and is also seen as the mapping and measuring of relationships and flows between people, groups, organizations, computers or other information/knowledge processing entities (Krebs, 2002). The nodes in a network are the people and groups while the links represent the relationships or flows between the nodes. Rather than focusing on the permanent attributes of people, objects or events, the social network perspective views the characteristics of those people as arising out of a relational process (Wasserman \& Faust, 1994).

The fundamental concepts in network analysis are actor, relational tie, dyad, triad, subgroup, group, relation and network (Wasserman \& Faust, 1994). Wellman (1988) ascertained that network theory shifts the focus from atomistic explanations of phenomena (attributes of independent cases) to relationships among systems of dependent actors. Hence, none of the statistical techniques that build upon the assumption of independent observations is appropriate for such an analysis. Instead, exploratory (e.g. Borgatti, Everett \& Freeman, 2002 (UCINET); de Nooy, Mrvar, \& Batagelj , 2005; Pajek-Batagelj \& Mrvar, 2005) and confirmatory (e.g. StocNet and SIENA (Snijders, 2001, 2002; Snijders, Pattison, Robins, \& Handcock, 2004)) network analysis tools and techniques started to evolve to provide support for researchers interested in the examination of relational phenomena, such as organizational learning.

The experience of authors up to date suggest that researchers can benefit greatly from exploratory techniques and measures above all in testing claims characteristics of most central organizational members (DC1), validating consistency in learning relationships (DC4), visualizing learning networks and clusters within (DC5), examining multiplexity and overlaps with other forms of networks (DC6), and comparing network at various points in time (DC7). More advanced, confirmatory social network analysis techniques, on other hand, aid in testing claims about centrality (DC1), homophily and proximity (DC2), reciprocity (DC3), consistency (DC4), small world theory (DC5), and partially also in testing the dynamic development of learning networks (DC7) even though their current use is limited to the stabile core of the company (neglecting the workforce who left the company).

\section{Conclusion}

The paper offers overview of the organizational learning field and its development through time. At present academic society is being witness of two contrasting perspectives to the understanding of organizational learning process: the acquisition and the participation perspective. Authors have expressed the need to develop a unifying and overarching framework. The authors develop network perspective to the intra-organizational learning that aims to merge both perspectives by building upon multiple theories of social networks and by applying multiple levels of analysis (individual, group, intra-organizational, as well as relational) which is the major contribution of this paper.

Paper offers seven descriptive claims, which build upon theories of homophily and proximity, cognitive theories, theories of social exchange and resource interdependence, theories of cognitive balance, theory of generalized exchange, theory of small worlds, social process theory, transactive memory systems, theories of network evolution, and spinning-top model of organizational learning. The basic contribution of this article is that it merges two disparate perspectives and 
offers a new path towards deeper understanding of organizational learning. It means departure from 'why' to 'how, from breadth to depth, in understanding of organizational learning processes.

However, there is still a lot of future work ahead. The seven descriptive claims offered are in need of empirical investigation. Using exploratory and confirmatory $\left(\mathrm{p}^{*}\right)$ social network analysis techniques and methods authors are collecting and analyzing data from organizations from various industries, sectors, countries etc in order to test the proposed claims and build a firm learning network theory which will have significant theoretical as well as practical implications and hence contribute to the advancement of organizational learning field of research and practice.

Not to forget, all individuals, teams, organizations and even groups of organizations learn but the pace and depth at which they do that is heavily related to their success. And this is particularly true for rapid and turbulent environments as the knowledge era is.

\section{References}

Aldrich, H. (1972). Organizational boundaries and inter-organizational conflict. Human Relations, 24, 279293.

Argyris, C. \& Schön, D. A. (1978). Organizational learning: A theory of action perspective. Reading, MA: Addison-Wesley.

Bapuji, H. \& Crossan, M. (2004). Reviewing organizational learning research - From questions to answers. Management Learning, 35, 4, 397-417.

Bartel, C.A. \& Garud, R. (2004). Narrative knowledge in action: Adaptive abduction as a mechanism for knowledge creation and exchange in organizations. In M. Easterby-Smith \& M. Lyles (Eds.), Handbook of organizational learning and knowledge management. Oxford: Blackwell Publishing.

Baum, J. A. C. (1996). Organizational ecology. In S. Clegg, C. Hardy, \& W. Nord (Eds.), Handbook of organization studies (pp.77-114). Thousand Oaks, CA: Sage.

Blau, P. M. (1955). The dynamics of bureaucracy (2nd ed.). Chicago, IL: The University of Chicago Press.

Blau, P. M. (1964). Exchange and power in social life. New York: Wiley.

Bontis, H., Crossan, M., \& Hulland, J. (2002). Managing an organizational learning system by aligning stocks and flows. Journal of Management Studies, 39(4), 437-469.

Borgatti, S., Everett, M. \& Freeman, L. (2002). UCINET for Windows. Analytic Technologies Inc. Accessed August 23, 2006 at: http://www.analytictech.com/ucinet/ucinet_5_description.htm

Brass, D. J. (1995). A social network perspective on human resources management. Research in Personnel and Human Resources Management, 13, 39-79.

Brown, J.S. \& Duguid, P. (1991). Organizational learning and communities- of-practice: Toward a unified view of working, learning, and innovation. Organization Science, 2(1), 40-57.

Burke, S. C., Stagl, K. C., Klein, C., Goodwin, G. F., Salas, E., \& Halpin, S. M. (2006). What type of leadership behaviors are functional in teams? A meta-analysis. Leadership Quarterly, 17, 288-307.

Cangelosi, V.E. \& Dill, W.R. (1965). Organizational learning: Observations toward a theory. Administrative Science Quarterly, 10, 2, 175-203.

Cohen, W. M. \& Levinthal, D. A. (1990). Absorptive capacity: A new perspective on learning and innovation. Administrative Science Quarterly, 35.

Cook, S. D. N. \& Brown, J. S. (1999). Bridging epistemologies: The generative dance between organizational knowledge and organizational knowing. Organization Science, 10(4), 381-400.

Cross, R. \& Parker, A. (2004). The hidden power of social networks. Boston, MA: Harvard Business School Press.

Cross, R., Parker, A., Prusak, L. \& Borgatti, S. P. (2001). Knowing what we know - Supporting knowledge creation and sharing in social networks. Organizational Dynamics, 30(2), 100-120. 
Cross, R. \& Prusak, L. (2004). The political economy of knowledge markets in organizations. In M. Easterby-Smith \& M. Lyles (Eds.), Handbook of organizational learning and knowledge management. Oxford: Blackwell Publishing.

Crossan, M. M., Lane, H., White, R. E. \& Djurfeldt, L. (1995). Organizational learning: Dimensions for a theory. The International Journal of Organizational Analysis, 3, 337-60.

Cyert, R.M. \& March, J.G. (1963). A behavioral theory of the firm. Englewood Cliffs, NJ: Prentice-Hall.

Daft, R.L. \& Weick, K.L. (1984). Toward a model of organizations as interpretation systems. Academy of Management Review, 9(2), 284-95.

Darr, E. D., Argote, L., \& Epple, D. (1995). The acquisition, transfer, and depreciation of knowledge in service organizations: Productivity in franchises. Management Science, 41(11), 1750-1762.

Day, G. S. (1994). Continuous learning about markets. California Management Review, Summer, 9-31.

de Geus, A. P. (1988). Planning as learning. Harvard Business Review, 88 (2), 70 -74.

de Nooy, W., Mrvar, A. \& Batagelj, V. (2005). Exploratory social network analysis with Pajek. New York: Cambridge University Press.

Dewey, J. (1916). Democracy and education: An introduction to the philosophy of education. London: Collier-Macmillian.

Dimovski, V. (1994). Organizational learning and competitive advantage: A theoretical and empirical analysis, (Doctoral Dissertation, Cleveland: [V. Dimovski]).

Dimovski, V., \& Škerlavaj, M. (2005). Performance effects of organizational learning in a transitional economy. Problems and Perspectives in Management, 3(4), 56-67.

Dodgson, M. (1993). Organizational learning - A review of some literatures. Organization Studies, 14(3), $375-94$.

Easterby-Smith, M. (1997). Disciplines of organizational learning: Contributions and critiques. Human Relations, 50 (9), 1085-113.

Easterby-Smith, M., Crossan, M. \& Nicolini, D. (2000): Organizational learning: Debates past, present and future. Journal of Management Studies, 37(6), 783-96.

Easterby-Smith, M. \& Lyles, M. (2004). Introduction - The watersheds of organizational learning and knowledge management. In M. Easterby-Smith \& M. Lyles (Eds.), Handbook of organizational learning and knowledge management. Oxford: Blackwell Publishing.

Easton, G. (1992). Industrial Network - A Review. In B. Axelsson, Easton, G. (Eds.): Industrial Networks A New View of Reality, London: Routledge.

Elkjaer, B. (2004). Organizational learning - The third way. Management Learning, 35(4), 419-434.

Emerson, R. M. (1962). Power-dependence relations. American Sociological Review, 27, 31-41.

Epple, D., Argote, L., \& Devadas, R. (1991). Organizational learning curves: A method for investigating inter-plant transfer of knowledge acquired through learning by doing. Organization Science, 2(1), 5870.

Festinger, L., Schachter, S., \& Back, K. (1950). Social pressures in informal groups: A study of human factors in housing. Palo Alto, CA: Stanford University Press.

Fiol. C. M. \& Lyles, M. A. (1985). Organizational learning. Academy of Management Review, 10(4), 80313.

Granovetter, M. (1992). Problems of Explanation in Economic Sociology. In N. Nohria, R. G. Eccles (Eds.), Networks and Organizations (pp. 25-56). Cambridge, MA: Harvard Business School Press.

Heald, M. R., Contractor, N. S., Koehly, L., \& Wasserman, S. (1998). Formal and emergent predictors of coworkers' perceptual congruence on an organization's social structure. Human Communication Research, 24, 536-563. 
Hedberg, B. (1981). How organizations learn and unlearn. In P.C. Nystrom \& W.H. Starbuck (Eds.), Handbook of organizational design. London: Cambridge University Press.

Hollingshead, A. B. (2000). Perceptions of expertise and transactive memory in work relationships. Group Processes and Intergroup Relations, 3, 257-267.

Homans, G. C. (1950). The human group. New York: Harcourt Brace.

Homans, G. C. (1958). Social behavior as exchange. American Journal of Sociology, 19, 22-24.

Huber, G.P. (1991). Organizational learning: The contributing processes and the literature. Organization Science, 2(1), 88-115.

Jashapara, A. (2003). Cognition, culture, and competition: An empirical test of the learning organization. The Learning Organization, 10(1), 31-50.

Kim, D. H. (1993). The link between individual and organizational learning. Sloan Management Review, Fall, 37-50.

Kogut, B., Shan, W., \& Walker, G. (1993). Knowledge in the network and the network as knowledge: Structuring of new industries. In G. Grabher (Ed.), The embedded firm: On the socioeconomics of industrial networks (pp. 67-94). New York: Routledge.

Korzenny, F., \& Bauer, C. (1981). Testing the theory of electronic propinquity: Organizational teleconferencing. Communication Research, 8, 479-498.

Krackhardt, D. (1987). Cognitive social structures. Social Networks, 9, 109-134.

Krebs, V. (2004). An Introduction to Social Network Analysis. Accessed April 7, 2005 at http://www.orgnet.con/sna.html

Lave, J. (1988). Cognition in practice: Mind, mathematics, and culture in everyday life. Cambridge: Cambridge University Press.

Lave, J. \& Wenger, E. (1991). Situated learning: Legitimate peripheral participation. Cambridge: Cambridge University Press.

Lazega, E. (1992). The micropolitics of knowledge. New York: A. de Gruyter.

Lazega, E. (2001). The collegial phenomenon. Oxford: Oxford University Press.

Lazega, E. (2006): Collective learning. Lecture at the workshop Quantitative Methods in the Social Sciences. Groeningen, NL: European Science Foundation, 6.-15. 9. 2

Lazega, E., Lemercier, C., \& Mounier, L. (2006). A spinning top model of formal organization and informal behavior: Dynamics of advice networks among judges in a commercial court. European Management Review, 3(2), 113-122.

Lazega, E. \& Pattison, P. (2001). Social capital and social mechanisms and collective assets: The example of status auctions among colleagues. In N. Lin, K. Cook, \& R. Burt (Eds.), Social capital: Theory and research, New York: Aldine-de Gruyter, 185-208.

Lazega, E. \& van Duijn, M. (1997). Position in formal structure, personal characteristics and choices of advisors in a law firm: A logistic regression model for dyadic network data. Social Networks, 19, 375397.

Lee, S., Courtney, J., \& O’Keefe, R. (1992). A system of organizational learning using cognitive maps. International Journal of Management Science, 20.

Levinthal, D. A. \& March, J. G. (1993). The myopia of learning. Strategic Management Journal, 14, 95112.

Lindenberg, S. (1997). Grounding groups in theory: Functional, cognitive, and structural interdependencies. Advances in Group Processes, 14, 281-331.

Llorens Montes, F. J., Ruiz Moreno, A., \& Garcia Morales, V. (2005). Influence of support leadership and teamwork cohesion on organizational learning, innovation and performance: an empirical examination. Technovation, 25, 1159-1172. 
March, J.G. (1991). Exploration and exploitation in organizational learning. Organization Science, 2(1), 71-87.

March, J.G. \& Simon, H.A. (1958). Organizations. New York: Wiley.

Milgram, S. (1967). The small world problem. Psychology Today, 2, 60-67.

Mitchell. J. C. (1969). The Concept and Use of Social Networks. In J.C. Mitchell (Ed.), Social networks in urban situations. Manchester: University of Manchester Press.

Monge, P. R., \& Contractor, N. S. (2003): Theories of communication networks. Oxford: Oxford University Press.

Monge, P. R., Rothman, L. W., Eisenberg, E. M., Miller, K. I. \& Kirstie, K. K. (1985). The dynamics of organizational proximity. Management Science, 31, 1129-1141.

Moreland, R. L. (1999). Transactive memory: Learning who knows what in work groups and organizations. In L. Thompson, D. Messick, \& J. Levine (Eds.), Sharing knowledge in organizations (pp. 3-31). Mahwah, NJ: Erlbaum.

Nicolini, D., Gherardi, S. \& Yanow, D. (2003). Knowing in organizations - A practice-based approach. Armonk, NY: M. E. Sharpe.

Nicolini, D. \& Meznar, M.B. (1995). The social construction of organizational learning: Concepts and practical issues in the field. Human Relations, 48(7), 727-46.

Pahor, M., Dlesk, M., Lisjak, M., \& Zdouc, N. (2004). Izkustvene skupnosti v podjetju Gorenje, d.d. In J. Prašnikar, D. Banović, \& B. Jazbec. Razvojno-raziskovalna dejavnost ter inovacije, konkurenčnost in družbena odgovornost podjetij. Ljubljana: Časnik Finance, 277-294 (In Slovene).

Pajek-Batagelj, V. \& Mrvar, V. (2005). Program for Large Network Analysis. Accessed on June 1, 2006 from http://vlado.fmf.uni-1j.si/pub/networks/pajek/

Pool, I. S., \& Kochen, M. (1978). Contacts and influence. Social Networks, 1, 1-48.

Romme, G., \& Dillen, G. (1997). Mapping the landscape of organizational learning. European Management Journal, 15(1), 68-79.

Sanchez, R. (2001). Knowledge management and organizational competence. Oxford, UK: Oxford University Press.

Sanchez, R. (2005). Knowledge management and organizational learning: Fundamental concepts for theory and practice. Lund Insitiute of Economic Research Working Paper Series, 2005/3.

Schwandt, D. \& Marquardt, M. (2000). Organizational learning: From world-class theories to global best practices. Boca Raton: St Lucie.

Sherif, M. (1958). Superordinate goals in the reduction of inter-group conflicts. American Journal of Sociology, 63, 349-356.

Shrivastava, P.A. (1983). Typology of organizational learning systems. Journal of Management Studies, 20, 1-28.

Simon, H. (1991). Bounded rationality and organizational learning. Organization Science, 2(1), 125-34.

Simonin, B. L. (1997). The importance of collaborative know-how: An empirical test of the learning organization. Academy of Management Journal, 40(5), 1150-1173.

Slater, S. F. \& Narver, J. C. (1995). Market orientation and learning organization. Journal of Marketing, 59(3), 63-74.

Snijders, T. A. B. (2001). The Statistical Evaluation of Social Network Dynamics. In M. E. Sobel \& M. P. Becker (Eds.), Sociological Methodology Volume 31, (pp. 361-395). Blackwell Publishing.

Snijders, T. A. B. (2002). Markov chain Monte Carlo estimation of exponential random graph models. Journal of Social Structure, 3.

Snijders, T.A.B., Pattison, P.E., Robins, G.L. \& Handcock, M.S. (2004). New specifications for exponential random graph models. Accessed on August 25, 2005 from http://stat.gamma.rug.nl/snijders/sprh_f.pdf 
Stata, R. (1989). Organizational learning: The key to management innovation. Sloan Management Review, 30 (Spring), 63-74.

Škerlavaj, M, \& Dimovski, V. (2006). Social network approach to organizational learning. Journal of Applied Business Research, 22(2), 89-97.

Tichy, N.M., Tushman, M.L. \& Fombrun, C. (1979). Social Network Analysis for Organizations. Academy of Management Review, 4(4), 507-519.

Turner, J. C., \& Oakes, P. J. (1989). Self-categorization theory and social influence. In P. B. Paulus (Ed.), Psychology of group influence (pp. 233-275). Hillsdale, NJ: Erlbaum.

Wasserman, S. \& Faust, K. (1994). Social network analysis. Cambridge, UK: Cambridge University Press.

Watts, D. J. (1999). Networks, dynamics, and the small-world phenomenon. American Journal of Sociology, 105(2), 493-527.

Wegner, D. M., Erber, R., \& Raymond, P. (1991). Transactive memory in close relationships. Journal of Personality and Social Psychology, 61, 923-929.

Wellman, B. (1988). Structural Analysis: From Method and Metaphor to Theory and Substance. In B. Wellman \& S. D. Berkowitz (Eds.), Social Structures: A Network Approach. New York: Cambridge University Press, pp. 19-61.

\section{Biography}

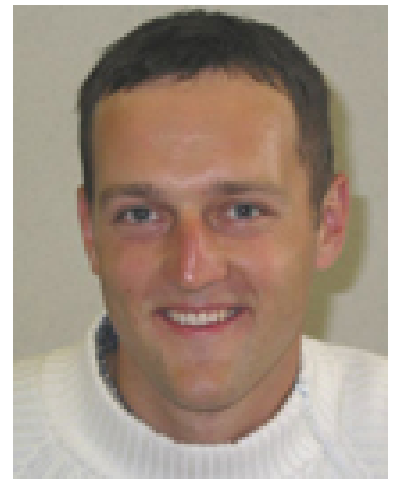

Miha Škerlavaj is a research and teaching assistant of management and organizational theory at the University of Ljubljana (Slovenia), Faculty of Economics. He has received his B.A. degree in Banking and finance (2001), and M.Sc. in Business informatics (2003) from Univeristy of Ljubljana. He also studied at the University of Nottingham, UK (2003). He holds a Ph.D. The title of his dissertation is Network Perspective and Performance of Organizational Learning: Theoretical and Empirical Analysis.

His research interest are: organizational learning and organizational performance, learning network analysis, and impact of IT on competitivness. He is an author and co-author of nine scientific and two professional articles, three scientific monographies and regurally publishes at the conferences worldwide. His bibliography is available at: http://splet02.izum.si/cobiss/bibliography?langbib=eng\&li=en\&code=23019.

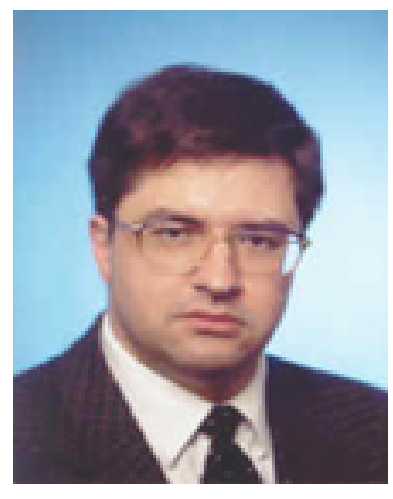

Vlado Dimovski is a full professor of management and organizational theory at the University of Ljubljana, Faculty of Economics in Slovenia. He holds B.A. degrees in Economics and Philosophy, M.A. in Economics, and Ph.D. in Management and Finance. As an academician Dimovski has taught and researched at the various universities and institutions, and has published numerous articles in recognized journals. His bibliography is available at: http://splet02.izum.si/cobiss/bibliography?langbib=eng\&li $=$ en $\&$ code $=0$ $\underline{8627}$.

His academic research interests cover learning organization, competitiveness, corporate strategy, developing knowledge-based organizations, and labor markets. Besides his university position professor Dimovski was the State Secretary for Industry (1995-97), the president of Center for International Competitiveness (19972005), and Minister for Labor, Family and Social Affairs (2000-2004). 